Siti Nurjanah|

\title{
KEEFEKTIFAN METODE PROBLEM BASED LEARNING (PBL) \\ PADA PEMBELAJARAN IPS TERHADAP HASIL BELAJAR PESERTA DIDIK SMPN 1 JETIS BANTUL
}

\author{
Siti Nurjanah \\ STIA Ambon, email: sitimology@gmail.com \\ Hp. 085643666629
}

\begin{abstract}
Abstrak
Penelitian ini bertujuan untuk mengetahui; 1) keefektifan metode PBL dibandingkan dengan metode ceramah dalam pembelajaran IPS terhadap hasil belajar IPS, 2) perbedaan hasil belajar IPS peserta didik pada kelompok motivasi tinggi dan rendah baik yang belajar dengan metode PBL dan yang belajar dengan metode ceramah dan, 3) interaksi antara metode pembelajaran dan motivasi terhadap hasil belajar IPS peserta didik. Penelitian ini merupakan penelitian kuasi eksperimen. Desain eksperimen yang digunakan merupakan pretest and postest group design dengan analisis faktorial $2 \times 2$. Sampel penelitian dua kelas yang ditentukan dengan teknik purposive random sampling dengan jumlah 60 peserta didik. Data diperoleh dengan: (1) tes, untuk mengukur hasil belajar IPS, dan (2) angket dengan skala Likert untuk menggolongkan motivasi tinggi dan motivasi rendah. Berdasarkan hasil analisis data dengan $\mathrm{a}=0,05$ kesimpulannya adalah sebagai berikut: (1) hasil belajar IPS peserta didik dengan metode PBL lebih tinggi dibandingkan dengan hasil belajar IPS peserta didik yang belajar dengan metode ceramah; (2) terdapat perbedaan hasil belajar IPS peserta didik pada kelompok motivasi tinggi dan kelompok motivasi rendah yang belajar dengan metode PBL dan yang belajar dengan metode ceramah; (3) terdapat interaksi antara metode pembelajaran dan motivasi dalam mempengaruhi hasil belajar IPS peserta didik.
\end{abstract}

Kata Kunci: problem-based learning, motivasi dan hasil belajar 


\begin{abstract}
This research to investigate 1) the effectiveness of the Problem-Based Learning (PBL) method in comparison with the lecturing method in Social Studies learning in terms of the students' learning outcomes, 2) the difference in learning outcomes based on the students' motivation between those learning through the $P B L$ method and those learning through the lecturing method, and 3) the interaction between the learning methods and students' motivation in terms of the learning outcomes of Social. This was a quasiexperimental study. The design was a pretest and posttest design with a $2 \times 2$ factorial analysis. The sample, selected by means of the purposive random sampling technique, consisted of two classes consisting of 60 students. The data were collected through: (1) tests to measure the Social Studies learning outcomes, and (2) a Likertscale questionnaire to classify the students' motivation into high and low motivation. Based on the data analysis at $a=0.05$, the conclusions are as follows. (1) The Social Studies learning outcomes of the students learning through the $P B L$ method are higher than those of the students learning through the lecturing method; (2) on differents the Social Studies learning outcomes of the students with motivation learning through and low motivation of the students learning through $P B L$ and the lecturing method ;(3) There is an interaction between the learning methods and motivation in terms of Social Studies learning outcomes of the students.
\end{abstract}

Keywords: problem-based learning, motivation, and learning outcome

\title{
Pendahuluan
}

Pendidikan sebagai upaya untuk mewujudkan sumber daya manusia yang berkualitas dan berdedikasi tinggi kepada bangsa dan Negara yang memerlukan suatu pendukung kuat dalam meningkatkan mutu pendidikan. Keberhasilan pendidikan tidak lepas dari peran pendidik yang mentransfer ilmu pengetahuan kepada peserta didik.

Pendidikan nasional harus mampu menjamin pemerataan kesempatan pendidikan, peningkatan mutu relevansi, dan efisiensi manajemen pendidikan. Pemerataan kesempatan pendidikan diwujudkan dalam program wajib belajar 9 tahun. Peningkatan 
Siti Nurjanah|

mutu pendidikan diarahkan untuk meningkatkan kualitas manusia Indonesia seutuhnya melalui olah pikir (aspek kognisi), olah rasa (aspek afeksi), dan olah kinerja (aspek psikomotoris) agar memiliki kompetensi bekerjasama dalam percaturan global. Pendidikan tidak hanya berorientasi pada masa lalu dan masa kini, tetapi sudah seharusnya merupakan proses yang mengantisipasi dan membicarakan masa depan, pendidikan hendaknya melihat jauh kedepan dan memikirkan apa yang akan dihadapi peserta didik dimasa yang akan datang (Trianto, 2011: 5).

Hal tersebut sesuai dengan Undang-Undang Sistem Pendidikan Nasional (Sisdiknas) Nomor 20 Tahun 2003 pasal 1 bahwa:

"Pendidikan adalah usaha sadar dan terencana untuk mewujudkan suasana belajar dan proses pembelajaran agar peserta didik secara aktif mengembangkan potensi dirinya untuk memiliki kekuatan spiritual keagamaan, pengendalian diri, kepribadian, kecerdasan, akhlak mulia serta keterampilan yang diperlukan dirinya, masyarakat, bangsa dan negara".

Merujuk pada pendapat tersebut di atas dapat dipahami bahwa pendidikan pada dasarnya merupakan proses untuk membantu peserta didik dalam mengembangkan potensi dirinya dan upaya sadar untuk menfasilitasi peserta didik dalam mengembangkan wawasan sehingga mampu menghadapi setiap perubahan yang terjadi. Kualitas pendidikan sangat diperlukan untuk mendukung terciptanya peserta didik yang cerdas, terampil dan mampu bersaing secara terbuka diera global. Kesuksesan proses pendidikan dan proses pembelajaran dipengaruhi oleh beberapa faktor antara lain guru, peserta didik, sarana prasarana, fasilitas belajar dan metode pembelajaran sehingga diperlukan upaya untuk mecapai tujuan tersebut terutama dalam pembelajaran IPS. 
Pembelajaran IPS dapat dipandang sebagai kerangka berfikir (frame of thinking) untuk mencapai tujuan dan kompetensi tertentu. Sesuai dengan lampiran Permendiknas Nomor 22 Tahun 2006 tentang Standar Isi (SI), bahwa substansi matapelajaranmatapelajaran sosial di SD/MI, SMP/MTs, dan SMK dikemas dalam matapelajaran IPS. Untuk melaksanakan amanah tersebut maka perlu diterapkan suatu metode, teknik, serta cara pandang yang tepat yang dapat memfasilitasi pelaksanaan pembelajaran IPS yang sifatnya padu, agar dapat membantu peserta didik dalam mencapai standar kompetensi yang ditentukan.

Upaya pencapaian tujuan pembelajaran IPS harus dilihat dari karakteristik perkembangan peserta didik dari segi perkembangan kognitif, afektif dan psikomotorik. Pada jenjang pendidikan SMP tahap perkembangan kognitif peserta didik berada pada tahap operasional kongkrit. Pada tahapan ini Piaget menyebutkan bahwa anak sudah dapat berfikir abstrak dan logis dengan prinsip hipotetis deduktif dan induktif, dalam hal ini anak berada pada usia 7/12 sampai 18 tahun (Asri Budiningsih, 2012: 39).

Guru mata pelajaran IPS diharapkan dapat memberikan motivasi dan kemampuan memecahkan masalah dalam proses kegiatan belajar mengajar. Dalam pembelajaran IPS diharapkan guru memiliki kecakapan dalam mentransfer pengetahuan dan pengalaman yang bermakna. Zamroni (2007: 264) menyatakan bahwa guru memiliki multi peran yang intinya menjadi inspirator, fasilitator dan motivator bagi peserta didik untuk menjadikan belajar di lingkungan sekolah menjadi lebih bermakna.

Dalam proses pembelajaran IPS, interaksi yang terjadi kadang berjalan searah. Dalam hal ini fungsi dan peran guru menjadi dominan, pada sisi lain, peserta didik hanya mendengarkan informasi atau pengetahuan yang diberikan gurunya. Hal ini 
Siti Nurjanah|

berakibat pada situasi yang kurang proporsional, guru sangat aktif, tetapi sebaliknya peserta didik menjadi pasif dan tidak kreatif. Bahkan kadang-kadang masih ada anggapan yang keliru, yang memandang guru sebagai sumber ilmu satu-satunya dan peserta didik sebagai objek sehingga peserta didik kurang dapat mengembangkan potensinya.

Berdasarkan pengamatan di SMP N 1 Jetis Bantul, peneliti menemukan beberapa permasalahan yang terkait dengan pembelajaran IPS yaitu peserta didik kurang aktif dan kurang motivasi dalam mengikuti pelajaran di kelas. Peserta didik terlihat kurang memperhatikan apa yang dijelaskan oleh guru dan ada pula yang tidak merespon pelajaran. Hal ini disebabkan dalam proses belajar mengajar guru hanya menggunakan metode ceramah. Masih terabaikannya kesempatan peserta didik untuk terlibat aktif dalam pembelajaran dan hanya terpusat pada guru, guru menjelaskan sebatas apa yang ada di dalam buku dan belum mengintegrasikan materi dalam kehidupan sehari-hari yang dialami peserta didik.

Pembelajaran IPS bersifat text book oriented peserta didik hanya dihadapkan pada tugas-tugas yang ada dibuku teks atau LKS yang dikerjakan secara individual sehingga kurang terlibat dalam kegiatan belajar mengajar. Kegiatan untuk membuat peserta didik aktif dalam pembelajaran IPS masih sangat kurang, tidak terdapat kegiatan diskusi, unjuk kerja tugas atau laporan belajar terkait dengan materi yang sedang dibahas.

Lemahnya kontrol guru terhadap hasil kerja peserta didik, hal ini terbukti kurangnya feedback atau masukan terkait dengan pekerjaan peserta didik di rumah maupun tugas yang dikerjakan di kelas. Perhatian guru terhadap peserta didik belum merata, hal ini terbukti dari peristiwa pada saat peserta didik tidak 
memperhatikan penjelasan guru, murid tidak diberikan peringatan. Peserta didik dalam melakukan aktifitas di kelas kurang, peserta didik tidak banyak yang mencoba bertanya kepada guru meskipun sudah diberikan kesempatan untuk melontarkan pendapat, hal ini terkesan bahwa peserta didik masih memiliki rasa tertutup dan sikap yang kurang merespon pelajaran IPS untuk mengeksplorasi pendapat saat kegiatan belajar mengajar berlangsung (Hasil observasi, Rabu 5 September 2012).

Metode ceramah kurang sesuai dalam pembelajaran IPS, karena konsep-konsep yang terkandung dalam matapelajaran IPS merupakan konsep yang memerlukan penalaran dalam pemecahan masalah. Dengan metode ini, peserta didik cenderung menghafal contoh-contoh yang diberikan guru tanpa terjadi pembentukan konsepsi yang benar dalam struktur kognitif peserta didik. Keadaan seperti ini membuat peserta didik mengalami kesulitan dalam memaknai materi sehingga beresiko tinggi terjadinya miskonsepsi. Tidak bermaknanya materi dan terjadinya miskonsepsi ini akan menyebabkan peserta didik mengalami kesulitan dalam memahami materi lebih lanjut dan akan berakibat pada hasil belajarnya.

Menyikapi permasalahan tersebut maka upaya perbaikan proses pembelajaran menjadi kebutuhan yang sangat krusial. Untuk itu, diperlukan metode pembelajaran efektif yang berorientasi pada proses dan aktivitas peserta didik dalam kegiatan pembelajaran, sehingga pemahaman peserta didik terhadap materi pelajaran menjadi meningkat.

\section{Karakteristik Siswa SMP}

Peserta didik jenjang SMP termasuk dalam kategori berpikir hipotetik, berada pada tahap masa-masa aktif sehingga sangat diperlukan metode yang tepat untuk membangkitkan motivasi, 
Siti Nurjanah|

daya pengetahuan, dan keterampilan hipotetisnya serta keterampilan dalam pemecahan masalah perlu untuk dieksplorasi. Salah satu upaya melalui penerapkan metode PBL (Problem-Based Learning) yang memberikan kesempatan kepada peserta didik untuk berpartisipasi secara aktif dalam pembelajaran dengan menghadapkan pada permasalahan-permasalahan praktis sebagai pijakan dalam belajar (Made Wena, 2011: 91).

Dalam kegiatan pembelajaran, motivasi dapat dikatakan sebagai keseluruhan daya penggerak di dalam diri peserta didik yang menimbulkan kegiatan belajar, yang menjamin kelangsungan dari kegiatan belajar dan yang memberikan arah pada kegiatan belajar, sehingga tujuan yang dikehendaki oleh subjek belajar itu dapat tercapai (Sardiman A. M., 2011: 75). Secara umum semakin tinggi motivasi peserta didik akan semakin baik pula hasil belajarnya. Namun demikian, sudah barang tentu suatu metode pembelajaran tidak selalu tepat untuk meningkatkan hasil belajar peserta didik yang berbeda motivasinya.

\section{Pendekatan Problem Based Learning}

Metode PBL merupakan metode pembelajaran yang berakar pada apersepsi pembelajaran yang berpusat pada penyajian permasalahan, yakni belajar adalah berbuat sesuatu untuk memecahkan permasalahan. Hal ini sesuai dengan pendapat Trianto (2011: 91) yang menyatakan bahwa metode PBL merupakan penyajian pembelajaran kepada peserta didik terhadap situasi masalah yang autentik dan bermakna yang dapat memberikan kemudahan kepadanya untuk melakukan penyelidikan atau inkuiri dengan menggunakan dunia nyata sebagai aktifitas belajar peserta didik, kegiatan ini akan dapat meningkatkan kreativitas, kemandirian dan hasil belajar peserta didik yang maksimal. 
Pembelajaran IPS dengan menggunakan metode PBL berupa aktifitas belajar yang melibatkan fisik dan mental. Kemampuan afektif dan psikomotorik dapat terproses secara bersamaan, karena ketika proses pembelajaran berlangsung akan terjadi hubungan dengan materi yang dipelajarinya dan ada pengalaman yang harus ditemukan sendiri oleh peserta didik dalam mengkonstruksikan pengetahuan dan pengalaman sendiri untuk memecahkan masalah yang dihadapi, dan menghadapkan peserta didik pada pemasalahan-permasalahan praktis sebagai pijakan dalam belajar (Made Wena 2011: 91). Metode PBL merupakan metode yang akan memacu keterlibatan peserta didik secara maksimal melalui berbagai kegiatan dan informasi yang konstruktif akan mendukung tercapainya kualitas proses dan hasil belajar yang berorientasi pada pencapaian tujuan yang jelas.

Hal tersebut sesuai dengan yang dijelaskan oleh Wood (2004: 2) bahwa di dalam penerapan metode PBL, pembelajar didorong untuk menggabungkan berbagai informasi. Pada tahap awal perlu melakukan pengecekan apakah informasi yang mereka dengarkan atau yang mereka baca itu benar dan mencoba untuk menggabungkan informasi baru dengan pengetahuan yang sebelumnya sudah mereka miliki. Dengan kemampuan tersebut peserta didik lebih percaya diri tentang apa yang sudah mereka dapatkan dan dapat berbagi dengan teman bahkan dapat mengembangkannya.

Penerapan metode PBL tidak hanya meningkatkan hasil belajar tetapi juga membekali peserta didik dengan pengalaman belajar menyelesaikan masalah sesuai materi pelajaran secara mandiri. Maka peneliti merumuskan alasan dari penggunaan metode PBL yaitu; 1) mendekatkan peserta didik dengan perkembangan situasi yang nyata; 2) membantu peserta didik mengembangkan 
Siti Nurjanah|

pemikiran dan keterampilan berfikir kritis agar memiliki kecakapan hidup; 3) menempatkan peserta didik sebagai subjek dan objek pembelajaran (Arends, 2007: 43). Dengan demikian, pembelajaran dengan metode PBL diharapkan akan terjadi interaksi yang baik antara peserta didik, guru, materi pelajaran, dan teman di kelas sehingga penguasaan materi IPS yang telah ditetapkan akan tercapai. Jika materi telah terkuasai dengan baik oleh peserta didik harapannya akan memberikan dampak positif terhadap pemaknaan proses belajar dan pencapaian hasil belajar IPS sehingga sesuai dengan tujuan yang diterapkan.

Dari pendapat di atas dapat ditegaskan bahwa metode PBL adalah metode pembelajaran yang difungsikan untuk mendukung daya kreatifitas berfikir peserta didik terhadap permasalahan yang tertentu dengan manajemen pengajaran yang bersifat demokratis dan terbuka serta peran aktif peserta didik. Dalam kegiatan pembelajarannya diharapkan sangat membantu peserta didik dapat menjadi pembelajar yang mandiri yang meyakini kemampuan intelektualnya dan aktif dalam lingkungan belajarnya.

\section{Metode Penelitian}

Penelitian ini menggunakan eksperimen semu. Terdapat dua kelompok subjek penelitian yang terdiri atas kelompok eksperimen dengan perlakuan metode PBL dan kelompok kontrol dengan metode ceramah. Penelitian dilakukan dengan menggunakan Pretest-Postest Control Group Design.

\section{Tabel 1}

Desain penelitian

\begin{tabular}{|c|c|c|c|}
\hline Kelompok & Pretes & Perlakuan & Postest \\
\hline $\begin{array}{c}\text { Eksperimen } \\
(\mathrm{E})\end{array}$ & $\mathrm{Y}_{1}$ & $\mathrm{X}_{1}$ & $\mathrm{Y}_{2}$ \\
\hline Kontrol (K) & $\mathrm{Y}_{3}$ & - & $\mathrm{Y}_{4}$ \\
\hline
\end{tabular}


JIPSINDO No. 2, Volume 1, September 2014

Keterangan:

E : Kelompok Eksperimen

K : Kelompok Kontrol

$\mathrm{Y}_{1} \quad$ : Pretest kelompok eksperimen

$\mathrm{Y}_{3} \quad$ : Pretest kelompok kontrol

$\mathrm{X}_{1}$ : Perlakuan dengan metode PBL

: Pembelajaran metode ceramah dengan media LKS

$\mathrm{Y}_{2} \quad$ : Posttest kelompok eksperimen

$\mathrm{Y}_{4} \quad$ : Posttest kelompok kontrol

Penelitian dilakukan di kelas VII D dan VII F SMP Negeri 1 Jetis, Bantul, DIY. Penelitian dilaksanakan antara bulan Januari sampai Maret 2013. Pada jangka waktu tersebut digunakan untuk uji coba instrumen, pretest, pelaksanaan penelitian dan postest. Populasi dan Sampel

Populasi dalam penelitian ini adalah peserta didik kelas VII SMP N 1 Jetis Bantul tahun pelajaran 2012/ 2013. Sampel dalam penelitian ini diambil melalui teknik random sampling. Penentuan kelas eksperimen dan kelas kontrol ditentukan secara random. Dari sejumlah populasi yang keseluruhan terbagi dalam 5 kelas, di random dan terpilih satu kelas yang akan dijadikan sampel penelitian. Kelas VIIF SMP N 1 Jetis dengan jumlah 30 peserta didik terpilih sebagai kelompok eksperimen dan 30 peserta didik di kelas kontrol.

Variabel yang gunakan dalam penelitian dengan menggunakan instrumen dan teknik analisis data tertentu. 1) Variabel bebas $\left(\mathrm{X}_{1}\right)$, dalam variabel ini terdiri atas dua metode yaitu PBL diterapkan di kelas eksperimen dan metode ceramah diterapkan di kelas kontrol. Metode PBL menempatkan peserta didik pada tugas kelompok untuk dipecahkan secara bersama dengan menggunakan aturan dan prosedur yang telah dipersiapkan oleh guru. 2) Variabel 
Siti Nurjanah|

kontrol $\left(\mathrm{X}_{2}\right)$, variabel kontrol dalam penelitian ini adalah variabel motivasi peserta didik. Motivasi yang diamati dalam penelitian ini dibedakan menjadi dua yaitu motivasi tinggi dan motivasi rendah. Variabel Terikat (Y), Variabel terikat dalam penelitian ini adalah hasil belajar IPS. Hasil belajar IPS meliputi aspek kognitif dan afektif peserta didik. Teknik pengumpulan data dalam penelitian ini menggunakan tes hasil belajar dan angket motivasi.

Validitas dan Reliabilitas

Validitas rasional mengacu pada pendapat ahli (expert judgment), sedangkan validitas empiris untuk instrumen tes hasil belajar menggunakan program ITEMAN version 3.00, untuk intrumen angket menggunakan program SPSS 16.00 for windows menggunakan nilai $\mathrm{r}$ hasil Corrected Item-Total Correlation melalui menu Scale pada Reliability Analysis. Nilai $r$ tabel pada taraf kepercayaan 95\% atau signifikansi 5\% $(\mathrm{p}=0,05)$ dapat diperoleh melalui df (degree of freedom) dengan menjumlahkan jumlah responden $(\mathrm{N})$ dengan jumlah butir pernyataan (k). Dengan demikian pertanyaan dikatakan valid jika nilai $r_{\text {tabel }}$ yang merupakan nilai dari Corrected Item-Total Correlation $>\mathrm{r}$ tabel.

Uji reliabilitas dilakukan dengan menggunakan formula alfa dari Cronbach dengan bantuan komputer yang menggunakan program SPSS 16.0 for Windows, yaitu apabila koefisien $a>0,7$ maka butir instrumen dianggap reliabel.

Teknik Analisis Data

Penelitian ini menggunakan teknik analisis yaitu ANAVA. ANAVA digunakan untuk menentukan apakah terdapat perbedaan signifikan secara statistik pada beberapa variabel yang terjadi secara serentak antara dua tingkatan dalam satu variabel. Untuk menguji perbedaan antar grup pada ANAVA, dilakukan dengan dua uji secara bersama-sama dan uji per variabel. 


\section{Hasil Penelitian dan Pembahasan}

Berdasarkan data yang diperoleh, skor angket motivasi peserta didik pada kelompok eksperimen dengan jumlah peserta didik 30 diperoleh rerata (mean) sebesar 75.93, variansi 30.89, median 76, standar deviasi 5.55, skor maksimal 84 dan skor minimal 63. Sedangkan berdasarkan data yang diperoleh, skor angket motivasi peserta didik pada kelompok kontrol dengan jumlah peserta didik 30 diperoleh rerata (mean) sebesar 72.97, variansi 16.72, median 74, standar deviasi 4.08, skor maksimal 80 dan skor minimal 63. Skor motivasi peserta didik yang lebih besar dari mean dipergunakan untuk menentukan kelompok peserta didik yang memiliki motivasi tinggi dan skor yang lebih rendah dari mean digunakan untuk menentukan kelompok peserta didik yang memiliki motivasi rendah.

Skor mean pada kelas ekperimen dan kelas kontrol memiliki perbedaan. Adapun nilai mean kelompok eksperimen adalah 75.93 sedangkan mean pada kelompok kontrol adalah 72.97. Pada kelompok eksperimen motivasi tinggi berjumlah 22 peserta didik dan kelompok motivasi rendah berjumlah 8 peserta didik. Sedangkan pada kelas kontrol data kelompok motivasi tinggi berjumlah 23 peserta didik sedangkan pada kelompok motivasi rendah berjumlah 7 peserta didik.Berikut adalah grafik persentase motivasi peserta didik pada kelas eksperimen dan kelas kontrol.

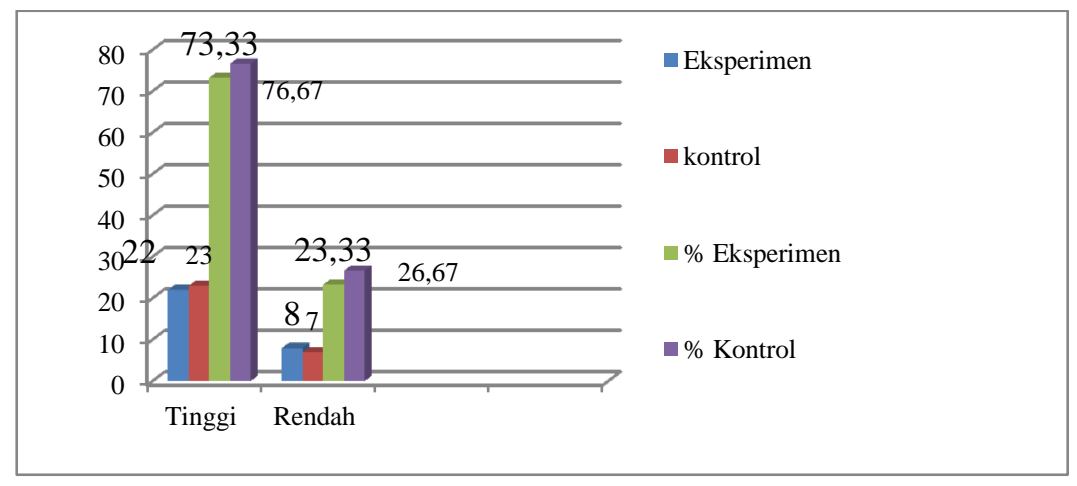

Gambar 1. Grafik Persentase Skor Perolehan Motivasi Peserta didik 
Siti Nurjanah|

Berdasarkan data yang telah diperoleh dapat ditegaskan bahwa motivasi peserta didik pada kelas eksperimen dan kelas kontrol memiliki perbedaan tetapi tidak signifikan. Kedua kelas tersebut memiliki skor motivasi yang hampir sama. Tetapi ada hal yang perlu diperhatikan dalam melihat motivasi peserta didik karena tidak semua peserta didik memiliki motivasi yang sama, sehingga harus lebih berhati-hati dalam memilih metode pembelajaran supaya hasil belajar IPS semua peserta didik baik yang memiliki motivasi tinggi dan peserta didik yang memiliki motivasi rendah dapat mencapai tujuan pembelajaran dengan seimbang.

Data tes hasil belajar IPS yang dideskripsikan terdiri atas data pretest dan data postest. Berikut adalah gambaran data pretest keas eksperimen dan kelas kontrol.

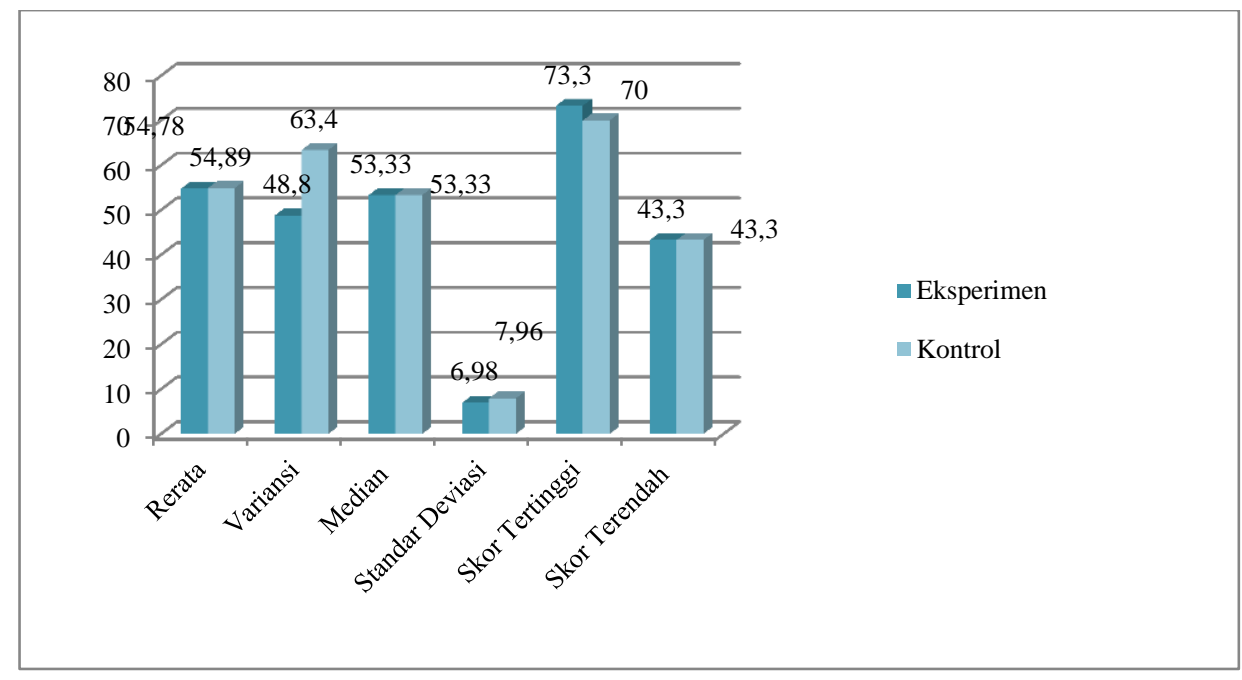

Gambar 2. Grafik Pretest Hasil Belajar

Dari data tersebut dapat dipahami bahwa data pretest hasil belajar IPS dalam penelitian ini diperoleh melalui uji tes dengan instrumen tes pilihan ganda. Dekripsi data pretest pada kelas eksperimen diperoleh rerata sebesar 54.78 varians, 48.8, median 53.33, standar deviasi 6.98, nilai maksimal 73.3 dan nilai minimal 
43.3. Sedangkan data yang diperoleh pada kelas kontrol adalah rerata sebesar 54.89, variansi 63.4, standar deviasi 7.96, nilai maksimal 70 dan nilai minimal 43.3. Sedangkan deskripsi data pretest dapat dijelaskan bahwa 30 peserta didik pada kelompok kontrol diperoleh rerata (mean) sebesar 54.89 varian 63.4, median 53.33, standar deviasi 7.96, nilai maksimal 70 dan nilai minimal 43.3.

Dari data tersebut tes hasil belajar untuk tahap pretest pada kelas eksperimen dan kelas kontrol memiliki perbedaan yang tidak signifikan. Hal ini memiliki arti bahwa untuk kedua kelas tersebut memiliki kemampuan awal yang sama. Dengan kemampuan yang sama tersebut kedua kelas eksperimen memungkinkan untuk diberikan metode pembelajaran yang berbeda sehingga akan terlihat perbedaan hasil belajar IPS nantinya.

Sedangkan untuk data postest kelompok eksperimen dan kelompok kontrol digambarkan dalam diagram batang di bawah ini untuk memperjelas perbedaan hasil belajar IPS peserta didik setelah dilakukan perlakuan baik pada kelas ekperimen maupun kelas kontrol. Berikut ini adalah tampilan data hasil belajar postets kelas eksperimen dan kelas kontrol

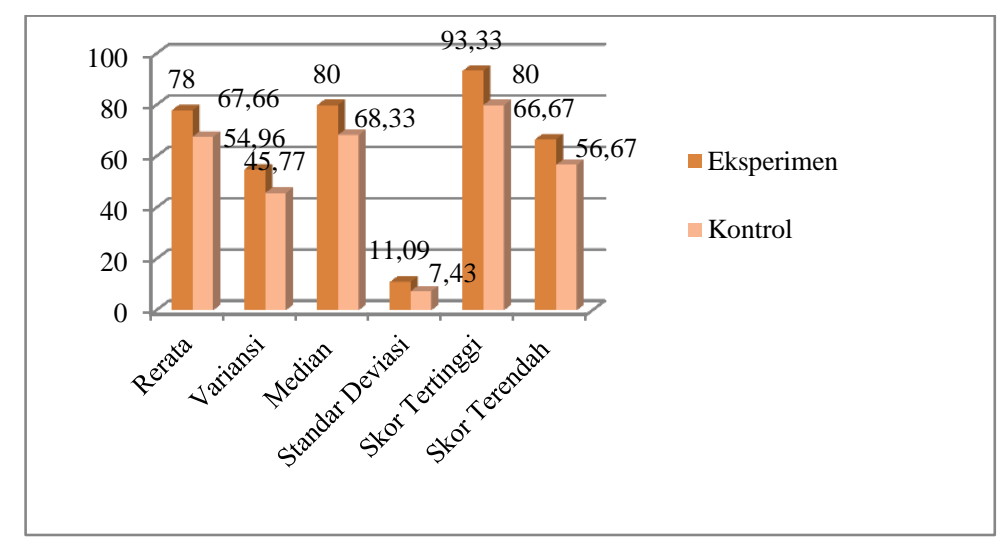

Gambar 3. Grafik Postest Hasil Belajar

Berdasarkan data diatas, maka hasil analisis data statistik deskriptif menunjukkan bahwa skor tertinggi pada kelompok 
Siti Nurjanah

kontrol dengan metode ceramah sebesar 80.00, skor terendah sebesar 56.67 dan untuk rata-rata nilai postest adalah sebesar 68.22. Sedangkan kelompok eksperimen dengan metode pembelajaran PBL skor tertinggi sebesar 93.33, skor terendah sebesar 66.67 dan untuk rata-rata nilai postest adalah sebesar 80.34. Artinya sudah memenuhi kriteria standar ketuntasan minimal yang telah ditetapkan.

Perhitungan prasyarat analisis dalam data penelitian ini terbagi menjadi dua hal yaitu uji normalitas dan uji homogenitas.

a. Hasil Perhitungan Normalitas

Perhitungan normalitas dilakukan dengan menggunakan program SPSS 16.0 For Windows. Hasil perhitungan normalitas sebelum perlakuan dapat dilihat pada tabel berikut ini. Dari tabel tersebut data menunjukkan bahwa variabel terikat hasil belajar IPS peserta didik sebelum perlakuan baik pada kelompok eksperimen maupun kelompok kontrol memiliki nilai signifikansi lebih dari 0,05. Oleh karena itu $\left(\mathrm{H}_{0}\right)$ dinyatakan bahwa "data berdistribusi normal" dapat diterima sehingga data tersebut berdistribusi normal.

b. Hasil Perhitungan Homogenitas pretest

Hasil perhitungan asumsi homogenitas dilakukan untuk menguji kesamaan terikat. Hasil perhitungan homogenitas menggunakan Levene Test dengan bantuan program SPSS 16.0 For Windows. Dari hasil perhitungan menunjukkan bahwa nilai signifikansi yang diperoleh adalah 0,187 dan bernilai lebih dari 0,05. Hal ini menunjukkan bahwa hipotesis $\left(\mathrm{H}_{0}\right)$ yang menyatakan bahwa "varians data dua kelompok adalah homogen" diterima. Oleh karena itu, variabel dependen kelompok eksperimen dengan kelompok ceramah memiliki varian yang homogen. 
c. Hasil Perhitungan Normalitas postets

Dalam penelitian ini uji normalitas dilakukan terhadap motivasi belajar dan hasil belajar IPS peserta didik setelah pelaksanaan eksperimen bagi kelompok eksperimen dan kelompok kontrol. Perhitungan normalitas dilakukan dengan menggunakan program SPSS 16.0 for windows. Berdasarkan data bahwa variabel terikat dan variabel bebas pada kelompok kontrol dengan metode pembelajaran ceramah maupun kelompok eksperimen dengan metode pembelajaran PBL memiliki nilai signifikansi lebih dari 0,05. Oleh karena itu, berdasarkan data yang ditampilkan di atas, maka hipotesis $\left(\mathrm{H}_{0}\right)$ diterima, artinya semua data atau sampel masing-masing berasal dari populasi yang berdistribusi normal.

d. Hasil Perhitungan Homogenitas postets

Hasil Perhitungan homogenitas dilakukan untuk mengetahui apakah populasi yang dibandingkan mempunyai variansi yang sama baik di kelas eksperimen maupun di kelas kontrol. Adapun hasil uji homogenitas dari motivasi belajar dan hasil belajar IPS peserta didik setelah pelaksanaan eksperimen tersebut dengan menggunakan levene's test. Hasil Perhitungan homogenitas dilakukan dengan menggunakan program SPSS 16.0 for windows. Berdasarkan tabel di atas, telihat bahwa signifikansi atau probabilitas yang diperoleh terhadap variabel independen motivasi belajar dan variabel dependen hasil belajar IPS peserta didik masing-masing adalah 0,412. Karena nilai-nilai tersebut lebih dari 0,05 , maka hipotesis $\left(\mathrm{H}_{0}\right)$ yang menyatakan "varians data dua kelompok adalah homogen" diterima. Oleh karena itu, berdasarkan hasil analisis yang dilakukan dengan menggunakan uji levene's test maka variabel 
Siti Nurjanah|

untuk motivasi belajar dan hasil belajar IPS peserta didik memiliki variansi yang homogen.

Dalam penelitian ini digunakan uji analisis variansi dua jalan dengan sel tak sama untuk mengetahui: (1) hasil belajar IPS peserta didik yang belajar dengan metode PBL lebih efektif jika dibandingkan dengan hasil belajar IPS peserta didik yang belajar dengan metode ceramah, (2) sama atau tidaknya rataan hasil belajar IPS peserta didik kelompok motivasi tinggi dan kelompok motivasi rendah yang belajar dengan metode PBL jika dibandingkan dengan hasil belajar IPS peserta didik pada kelompok motivasi tinggi yang belajar dengan metode pembelajaran ceramah, dan (3) interaksi antara kedua metode pembelajaran dan motivasi terhadap hasil belajar IPS. Berikut adalah hasil analisis variansi dua jalan dengan sel tak sama dalam penelitian ini:

Tabel 2. Hasil Uji Analisis Variansi Dua Jalan

\begin{tabular}{|c|c|c|c|c|c|c|}
\hline Sumber & $\mathrm{JkK}$ & $\mathrm{dk}$ & $\mathrm{RK}$ & $\mathrm{f}$ & $\mathrm{F}$ tabel & Keputusan Uji \\
\hline Model & 907,53 & 1 & 907,53 & 5,50 & 4,00 & $\mathrm{H}_{0}$ ditolak, $\mathrm{H}_{\mathrm{a}}$ di terima \\
\hline Motivasi & 3153,14 & 1 & 3153,14 & 19,12 & 4,00 & $\mathrm{H}_{0}$ ditolak, $\mathrm{H}_{\mathrm{a}}$ di terima \\
\hline Interaksi & 708,84 & 1 & 708,84 & 5,09 & 4,00 & $\mathrm{H}_{0}$ ditolak, $\mathrm{H}_{\mathrm{a}}$ di terima \\
\hline Galat & 9234,82 & 56 & - & - & - & - \\
\hline Total & 14004,23 & 58 & - & - & - & - \\
\hline
\end{tabular}

Berdasarkan data tersebut di atas dapat kita pahami bahwa:

a. Terdapat perbedaan signifikan antara hasil belajar peserta didik pada kelompok eksperimen dengan kelompok kontrol yaitu $\left(F_{o}=5.50>F_{\text {tabel }}=4,00\right.$. Dengan nilai $F_{\text {tabel }}=4,00$ berarti daerah kritiknya $\mathrm{DK}=\{\mathrm{F} \mid \mathrm{F}<4,00\}$. Jadi $\mathrm{F}_{\text {obs }}=5.50 \notin \mathrm{DK}$, berarti $\mathrm{H}_{0 \mathrm{~A}}$ ditolak (artinya kedua metode pembelajaran baik pada kelas eksperimen dan kelas kontrol mempunyai rataan yang tidak sama). Dengan kata lain rerata hasil belajar IPS peserta didik pada kelompok kontrol yaitu 80,44 lebih tinggi 
dari pada nila rerata hasil belajar IPS pada kelompok kontrol yaitu 68,22 .

b. Hasil analisis perbedaan hasil belajar IPS peserta didik berdasarkan motivasi peserta didik yang rendah dengan motivasi peserta didik yang tinggi diperoleh data nilai dari dari $\mathrm{F}_{\text {obs }}=19.02$ dan nilai dari $\mathrm{F}_{\text {tabel }}=4,00$. Dengan nilai $\mathrm{F}_{\text {tabel }}=$ 4,00 berarti daerah kritiknya $\mathrm{DK}=\{\mathrm{F} \mid \mathrm{F}>4,00\}$. Jadi $\mathrm{F}_{\text {obs }}=$ $19.02 \notin \mathrm{DK}$, berarti $\mathrm{H}_{\mathrm{OB}}$ ditolak (dari kedua kriteria motivasi belajar peserta didik pada kedua kelompok eksperimen dan kelompok kontrol memiliki rataan yang tidak sama). Dengan kata lain bahwa nilai hasil belajar IPS peserta didik yang memiliki motivasi tinggi dikelas eksperimen memiliki nilai lebih baik dibandingkan dengan nilai motivasi tinggi pada kelompok kontrol. Namun jika dilihat dari mean nilai hasil belajar IPS pada motivasi rendah di kelas eksperimen lebih rendah dibandingkan dengan nilai hasil belajar IPS yang memiliki motivasi rendah di kelas kontrol.

c. Hasil uji interaksi metode pembelajaran dengan motivasi terhadap hasil belajar IPS peserta didik di kelas eksperimen dan di kelas kontrol $(\mathrm{AB})$ memiliki data hasil bahwa, nilai dari dari $F_{o}=5.09$ dan nilai dari $F_{\text {tabel }}=4,00$. Dengan nilai $F_{\text {tabel }}=$ 4,00 , berarti daerah kritiknya $\mathrm{DK}=\{\mathrm{F} \mid \mathrm{F}>4.00\}$. Jadi $\mathrm{F}_{\mathrm{o}}=$ $5.09 \notin \mathrm{DK}$, berarti $\mathrm{H}_{\mathrm{OAB}}$ ditolak (artinya terdapat interaksi antara metode pembelajaran PBL dan ceramah pada motivasi belajar peserta didik terhadap hasil belajar IPS peserta didik). Berikut adalah gambaran hubungan interaksi antara kedua metode pembelajaran dan motivasi peserta didik terhadap perolehan hasil belajar peserta didik. 
Siti Nurjanah

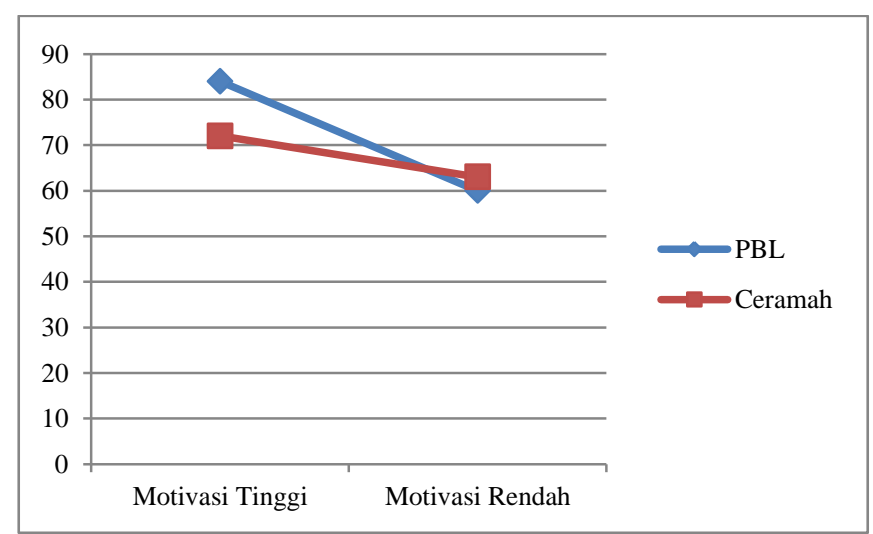

Gambar 4. Interaksi antara metode pembelajaran, motivasi dan hasil belajar

Hasil penggambaran interaksi antara metode pembelajaran dan motivasi peserta didik dapatdilihat dengan jumlah rata-rata dari keseluruhan nilai baik pada peserta didik yang memiliki motivasi tinggi dan rendah yang belajar dengan metode PBL maupun peserta didik yang belajar dengan metode ceramah. Berikut adalah tampilan data deskriptif dari masing-masing mean pada variabel metode pembelajaran dan variabel motivasi peserta didik.

Tabel.3 Mean Perolehan Nilai Pada Setiap Variabel

\begin{tabular}{|c|c|c|}
\hline $\begin{array}{l}\text { Metode } \\
\text { Motivasi }\end{array}$ & $\begin{array}{l}\text { PBL } \\
\text { (A1) }\end{array}$ & $\begin{array}{l}\text { Ceramah } \\
\text { (A2) }\end{array}$ \\
\hline $\begin{array}{c}\text { Tinggi } \\
\text { (B1) }\end{array}$ & $\begin{array}{l}\Sigma \mathrm{X} 1 \\
1846,68 \\
\mathrm{nA1B} 1=22 \\
\text { mean }=84\end{array}$ & $\begin{array}{l}\Sigma \mathrm{X} 3=1565,67 \\
\mathrm{nA} 2 \mathrm{~B} 1=23 \\
\text { mean }=72\end{array}$ \\
\hline Rendah (B2) & $\begin{array}{l}\Sigma X 2=480 \\
n A 1 B 2=8 \\
\text { mean }=60\end{array}$ & $\begin{array}{l}\Sigma \mathrm{X} 4=436,66 \\
\mathrm{nA2B} 2=7 \\
\text { mean }=63\end{array}$ \\
\hline
\end{tabular}

Berdasarkan data tersebut dapat dideskripsikan bahwa, hasil belajar peserta didik yang memiliki motivasi tinggi yang belajar dengan metode Problem Based Learning hasilnya lebih tinggi dibandingkan dengan hasil belajar peserta didik yang belajar dengan metode PBL yakni 84>72. Sedangkan hasil belajar peserta didik yang memiliki motivasi rendah yang belajar dengan Problem 
Based Learning hasilnya lebih rendah dibandingkan dengan metode ceramah yakni $60<63$. Pada data di atas dapat disimpulkan bahwa metode Problem Based Learning lebih baik diterapkan pada peserta didik yang memiliki motivasi tinggi, sedangkan metode ceramah cenderung lebih baik jika diterapkan pada peserta didik yang memiliki motivasi rendah.

Peserta didik yang memiliki motivasi tinggi akan lebih mudah untuk menerima metode pembelajaran yang menantang pengetahuannya untuk mengeksplorasi sumber-sumber yang dapat dijadikan sebagai pengalaman dalam belajarnya. Sedangkan peserta didik dengan motivasi rendah akan cenderung tertinggal karena kurang aktif dalam mengeksplorasi pengetahuannya. Mereka cenderung menyukai pembelajaran yang tidak membutuhkan eksplorasi pengetahuan secara mandiri, sehingga akan tertinggal jika menggunakan metode Problem Based Learning yang pada dasarnya menerapkan pembelajaran yang bersifat mandiri.

\section{Simpulan}

Berdasarkan hasil penelitian, maka dapat ditarik suatu kesimpulan sebagai berikut: 1) Hasil eksperimen menunjukkan bahwa hasil belajar peserta didik yang belajar dengan metode Problem Based Learning lebih tinggi jika dibandingkan dengan hasil belajar peserta didik yang belajar dengan metode ceramah. Dengan lebih efektifnya metode Problem Based Learning diharapkan akan menghasilkan hasil belajar yang lebih baik namun masih perlu diberikan secara intensif. Pembelajaran Problem Based Learning akan lebih memudahkan mereka untuk mengekplorasi pengetahuan diri peserta didik untuk menyelesaikan setiap permasalahan. Penerapan metode PBL diharapkan dapat meningkatkan hasil belajar IPS peserta didik. 2) 
Siti Nurjanah|

Hasil belajar IPS peserta didik pada kelompok motivasi tinggi yang beajar dengan metode Problem Based Learning memiliki nilai yang lebih baik dibandingkan dengan hasil belajar peserta didik yang belajar dengan metode ceramah. Kelompok motivasi rendah yang belajar dengan metode PBL memiliki nilai yang lebih rendah dibandingkan dengan peserta didik yang belajar dengan metode ceramah. 3) Terdapat interaksi antara kedua metode pembelajaran dan motivasi belajar terhadap hasil belajar IPS peserta didik. Terdapatnya interaksi antara kedua metode pembelajaran dan motivasi belajar peserta didik artinya dapat diambil kesimpulan bahwa pada kelompok motivasi tinggi, hasil belajar IPS peserta didik yang belajar dengan metode pembelajaran PBL lebih tinggi dibandingkan dengan hasil belajar IPS peserta didik yang belajar dengan metode pembelajaran ceramah.

\section{Saran}

1. Dalam penerapan metode PBL guru sebaiknya menggunakan permasalahan nyata (riil problems) yang sering peserta didik saksikan dalam kehidupan sehari-hari.

2. Pengembang kurikulum mempunyai tugas dan tanggung jawab yang besar dalam rangka pelaksanaan pembelajaran. Oleh karena itu, disarankan agar pengembang kurikulum mengembangkan perangkat pembelajaran PBL karena terbukti lebih efektif dalam meningkatkan hasil belajar peserta didik.

3. Peserta didik diharapkan dapat memanfaatkan potensi yang dimilikinya. Dengan penggunaan model pembelajaran PBL, peserta didik agar lebih termotivasi dalam belajar sekaligus mengupayakan hubungan interaktif antara peserta didik dengan pendidik. 


\section{Daftar Pustaka}

Arends, R.(2007). Learning to teach. (Terjemahan Helly Prajitno Soecipto dan Sri Mulyatini Soecipto. Yogyakarta: Pustaka Pelajar.

Arends, R. I., \& Kilcher, A. (2010). Teaching for student learning (becoming an accomplished teacher). Newyork and London: Routledge Ratlor and Francis Group.

Darmiyati Zuchdi. (2008). Humanisasi pendidikan: menemukan kembali pendidikan yang manusiawi. Jakarta: Bumi Aksara.

Depdiknas. (2003) Undang-Undang RI Nomor 20 Tahun 2003 tentang Sistem Pendidikan Nasional.

Depdiknas. (2006) Peraturan menteri nasional RI nomor 22 tahun 2006 tentang Standar isi lampiran 2 standar pendidikan dan kompetensi dasar tingkat SMP/MTS dan SMPLB.

Glazer, E. 2001. Problem based instruction from emerging prespectives on learning teaching and technology. Diakses $\begin{array}{llll}\text { pada } & \text { tanggal } & 8 & \text { September }\end{array}$ darihttp://www.projects.coe.uga.edu/epltt/index.php?titlle= Problem_based Instruction.

Made Wena. (2011) Strategi pembelajaran inovatif kotemporer. Jakarta: Bumi Aksara.

Sardiman A.M. (2011). Interaksi \& motivasi belajar mengajar. Jakarta: PT Raja Grafindo Persada.

Trianto. (2011). Mendesain model pembelajaran inovatif progresif. Jakarta: Kecana.

Wina Sanjaya. (2009). Strategi pembelajaran berorientasi standar proses pendidikan. Jakarata: Bumi Aksara.

Wood EJ. 2004. Problem-based learning: exploting knowledge of how people learn to promote effective learning. Diakses pada tanggal 12 Desember
http://bio.itsn.ac.uk/journal/vol 3.

Zamroni. (2007). Pendidikan dan demokrasi dalam transisi. Jakarta: PSAP Muhammadiyah. 